\title{
Relationship Of Compensation, And Authoritary Leadership Styles And Employee Performance
}

\author{
Ely Rohmawati dan Ani Wulandari \\ Program Studi Manajemen, Fakultas Ekonomi Dan Bisnis \\ Universitas Narotama Surabaya \\ Email Author: ani.wulandari@narotama.ac.id
}

\begin{abstract}
This study aims to determine the relationship between compensation and authoritarian leadership style with employee performance at PT. Circle K Indonesia Utama Surabaya. The number of respondents in this study was 68 employees. The research method used is descriptive, validity test, reliability test, and spearman rank correlation calculation. The results showed that the compensation variables and authoritarian leadership style had a strong and significant relationship with employee performance. Strategies that can be applied by PT. Circle K Indonesia Utama Surabaya to improve employee performance, namely paying more attention to activities and providing employee compensation appropriately and accordingly. Also, improve the leadership style used by leaders.
\end{abstract}

\section{Keyword:}

Compensation, Authoritarian Leadership Style, Employee Performance.

\section{Pendahuluan \\ 1.1.Latar Belakang}

Dalam suatu perusahaan khususnya dibidang ritel, karyawan merupakan ujung tombak suatu perusahaan dimana para karyawan tersebut terjun langsung dilapangan dengan membawa nama perusahaan. Perusahaan dituntut untuk dapat menciptakan kinerja karyawan yang tinggi dalam pengembangannya, karena keberhasilan suatu perusaahaan tersebut dipengaruhi oleh beberapa faktor yang salah satunya adalah sumber daya manusia atau kinerja karyawan tersebut. Kinerja sendiri merupakan kualitas ataupun kuantitas yang dicapai oleh seorang pegawai dalam melaksanakan tugasnya sesuai dengan tanggung jawab yang telah diberikan (Mangkunegara(2005:67)

Dalam upaya menciptakan kinerja karyawan yang baik, perusahaan berupaya untuk dapat memenuhi kebutuhan para karyawannya. Selain itu, perusahaan harus mampu menciptakan kondisi yang dapat mendorong para karyawan untuk dapat mengembangkan dan juga meningkatkan kemampuan serta keterampilan yang dimiliki secara maksimal.

Salah satu upaya yang dilakukan adalah pemberian kompensasi. Kompensasi adalah Sesuatu yang diterima karyawan sebagai balas jasa untuk kerja mereka (Handoko:1994). Dalam kepegawaian, hadiah yang bersifat uang adalah kompensasi yang diberikan kepada para karyawan sebagai penghargaan dari pelayanan tersebut. Selain itu, peran seorang pemimpin atau gaya kepemimpinan juga merupakan faktor yang sangat penting dalam meningkatkan kinerja para karyawan dalam suatu perusahaan. Karena baik tidaknya bawahan melaksanakan tugas mereka tergantung dari pimpinan sendiri.

Dalam kenyataannya, tidak semua pimpinan berperilaku baik ataupun mampu menciptakan suasana kerja yang kondusif dan kekeluargaan. Banyak dijumpai pimpinan dengan kepemimpinannya yang bersikap egois dan tidak mau memberikan semangat kerja kepada para karyawan. Kepemimpinan yang tidak efektif dan kurang memperhatikan karyawannya, biasanya menyebabkan perasaan tidak senang terhadap atasan tersebut yang diwujudkan dalam bentuk sikap bermalas-malasan dalam bekerja ataupun kurang bersemangat dalam menanggapi setiap tugas yang diberikan oleh pimpinan tersebut, bahkan banyak juga yang memutuskan untuk berhenti bekerja.

Pada perusahaan di bidang ritel yang berada di Surabaya ini sedang mengalami sebuah masalah yaitu tentang keluar masuknya karyawan baru juga menurunnya kinerja karyawan, sebenarnya terjadinya masalah tersebut adalah suatu hal yang tidak dikehendaki oleh sebuat perusahaan. Hal ini disebabkan karena faktor kompensasi yang dirasa kurang sesuai dengan pekerjaan. Juga disebabkan karena hubungan antara bawahan dengan atasan yaitu gaya kepemimpinan seorang atasan dalam menciptakan sebuah lingkungan kerja yang nyaman bagi karyawan.

Karyawan merasa tidak nyaman dalam bekerja bukan karena lingkungan pekerjaan itu saja, tetapi mereka juga tidak puas dengan gaji/upah yang diterima yang dirasa tidak sesuai dengan aktifitas pekerjaan yang mereka lakukan. Juga para atasan mereka yang dirasa sewenang-wenangnya. Hal ini menjadi alasan mengapa mereka 
menjadi malas-malasan dalam bekerja bahkan keluar dari pekerjaan dan memilih untuk mencari pekerjaan baru. Oleh karena itu perlu dilakukan penelitian untuk memberikan solusi kepada perusahaan tersebut, agar karyawan baru maupun lama betah dalam bekerja di perusahaan tersebut dan keluar masuknya karyawanpun dapat berkurang.

Adapun yang menjadi dasar pemikiran peneliti adalah sebagai berikut: tentang "Hubungan Kompensasi Dan Gaya Kepemimpinan Otoriter Dengan Kinerja Karyawan (Studi Kasus PT. Circle K Indonesia Utama Surabaya)"

\subsection{Perumusan Masalah} adalah:

Berdasarkan uraian pada latar belakang masalah tersebut, maka perumusan masalah dalam penelitian

1. Apakah Kompensasi memiliki hubungan yang signifikan dengan Kinerja Karyawan ?

2. Apakah Gaya Kepemimpinan Otoriter memiliki hubungan yang signifikan dengan Kinerja Karyawan ?

\section{Tinjauan Pustaka}

\subsection{Penelitian Terdahulu}

Sebelum penelitian ini dilakukan, banyak penelitian-penelitian terdahulu yang telah dilakukan tentang kompensasi dan gaya kepemimpinan terhadap kinerja karyawan yang berkaitan dengan Hubungan Variabel Kompensasi dan Gaya Kepemimpinan Terhadap Kinerja Karyawan PT Circle K Indonesia Utama Surabaya.

Penelitian Renggani Nur'aini Vidianingtyas, Wika Harisa Putri (2014) dengan judul "pengaruh kompensasi, kepuasan kerja, motivasi kerja dan gaya kepemimpinan terhadap kinerja karyawan pada perusahaan jasa catering di Daerah Istimewa Yogyakarta (2014)". Tujuan dari penelitian ini adalah untuk menguji dan menganalisis pengaruh kompensasi, kepuasan kerja, motivasi kerja dan gaya kepemimpinan terhadap kinerja karyawan pada perusahaan jasa catering di Daerah Istimewa Yogyakarta. Terdapat perbedaan peneliti tersebut dengan penelitian peneliti, dimana penelitian Renggani menggunakan metode analisis regresi linier berganda sedangkan peneliti menggunakan metode korelasi. Di penelitian Renggani tersebut menggunakan variabel bebasnya kompensasi, kepuasan kerja, motivasi kerja dan gaya kepemimpinan sedangkan peneliti variabel bebasnya adalah kompensasi dan gaya kepemimpinan.

\subsection{Rerangka Teori}

\subsubsection{Kinerja}

1. Pengertian Kinerja

Kinerja (prestasi kerja) adalah hasil kerja secara kualitas dan kuantitas dicapai oleh seorang pegawai atau karyawan dalam melaksanakan tugasnya sesuai dengan tanggung jawab yang telah diberikan (Mangkunegara, 2005:67).Menurut Siagian (2003) Kinerja adalah konsep yang bersifat universal yang merupakan efektifitas operasional suatu organisasi, bagian organisasi dan bagian karya berdasarkan standard dan kriteria yang ditetapkan. Kinerja merupakan hasil kerja seseorang atau lebih selama periode tertentu dibandingkan dengan berbagai kemungkinan, misalnya standar, target atau criteria yangb telah ditentukan terlebih dahulu dan telah disepakati bersama. (Robbins 2008)

2. Pengukuran kinerja karyawan berikut ini"

Dharma (2003:355) mengatakan "Hampir semua cara pengukuran kinerja mempertimbangkan hal-hal

a. Kuantitas

Jumlah yang harus diselesaikan atau dicapai. Melibatkan perhitungan keluaran dari proses atau pelaksanaan kegiatan.

b. Kualitas

Merupakan mutu yang harus dihasilkan. Pengukuran kualitatif mencerminkan pengukuran tinkat kepuasan yaitu seberapa baik penyelesaiannya.

c. Ketepatan waktu

Tingkat aktivitas diselesaikan pada waktu yang ditetapkan atau sesuai tidaknya dengan waktu yang direncanakan.

\subsubsection{Kompensasi}

1. Pengertian Kompensasi

Menurut Hariandja (2005) Kompensasi adalah keseluruhan balas jasa yang diterima oleh pegawai sebagai akibat dari pelaksanaan pekerjaan di organisasi dalam bentuk uang atau yang lainnya, yang dapat berupa gaji, upah, bonus, insentif dan tunjangan lainnya seperti tunjangan kesehatan, tunjangan hari raya, uang makan, uang cuti, dan lain-lain. 
Rivai dan Sagala (2009) mendefinisikan kompensasi adalah sesuatu yang diterima karyawan sebagai pengganti kontribusi jasa mereka pada perusahaan. Kompensasi merupakan biaya utama atas keahlian atau pekerjaan dan kesetiaan dalam bisnis perusahaan. Kompensasi menjadi salah satu alasan mengapa kebanyakan orang mencari pekerjaan.

Dari sekian pengertian yang di kemukakan di atas, dapat disimpulkan bahwa kompensasi adalah sebagai bentuk imbal jasa yang diberikan kepada karyawan sebagai bentuk penghargaan terhadap kontribusi dan pekerjaan mereka kepada perusahaan.

\section{Indikator-Indikator Kompensasi}

Indikator-indikator kompensasi menurut Simamora (2004:445) diantaranya :

a. Upah dan gaji.Upah biasanya berhubungan dengan tarif gaji per jam. Upah merupakan basis bayaran yang kerapkali digunakan bagi pekerja-pekerja produksi dan pemeliharaan. Gaji umumnya berlaku untuk tarif bayaran mingguan, bulanan atau tahunan.

b. Insentif.Insentif adalah tambahan kompensasi di atas atau di luar gaji atau upah yang diberikan oleh organisasi.

c. Tunjangan.Contoh-contoh tunjangan adalah asuransi kesehatan dan jiwa, liburan yang ditanggung perusahaan, program pension, dan tunjangan lainnya yang berkaitan dengan hubungan kepegawaian.

d. Fasilitas.Contoh-contoh fasilitas adalah kenikmatan/fasilitas seperti mobil perusahaan, keanggotaan klub, tempat parkir khusus, atau akses ke pesawat perusahaan yang diperoleh karyawan. Fasilitas dapat mewakili jumlah substansial dari kompensasi, terutama bagi eksekutuf yang dibayar mahal.

\subsubsection{Gaya Kepemimpinan}

\section{Pengertian Kepemimpinan}

Kepemimpinan atau leadership merupakan kemampuan mendorong sejumlah orang (dua orang atau lebih) agar bekerjasama dalam melaksanakan kegiatan-kegiatan yang terarah pada tujuan bersama. Ada banyak pengertian yang dikemukakan oleh para pakar menurut sudut pandang masing-masing, definisi-definisi tersebut menunjukkan adanya beberapa kesamaan.Pengertian Kepemimpinan Menurut Para ahli :

a. Menurut Tead; Terry; Hoyt (dalam Kartono, 2003) Pengertian Kepemimpinan yaitu kegiatan atau seni mempengaruhi orang lain agar mau bekerjasama yang didasarkan pada kemampuan orang tersebut untuk membimbing orang lain dalam mencapai tujuan-tujuan yang diinginkan kelompok.

b. Menurut Young (dalam Kartono, 2003) Pengertian Kepemimpinan yaitu bentuk dominasi yang didasari atas kemampuan pribadi yang sanggup mendorong atau mengajak orang lain untuk berbuat sesuatu yang berdasarkan penerimaan oleh kelompoknya, dan memiliki keahlian khusus yang tepat bagi situasi yang khusus.

Dari beberapa definisi diatas dapat disimpulkan bahwa kepemimpnan merupakan kemampuan mempengaruhi orang lain, bawahan atau kelompok, kemampuan mengarahkan tingkah laku bawahan atau kelompok, memiliki kemampuan atau keahlian khusus dalam bidang yang diinginkan oleh kelompoknya, untuk mencapai tujuan organisasi atau kelompok.

2. Gaya Kepemimpinan Otoriter

Adalah gaya pemimpin yang memusatkan segala keputusan dan kebijakan yang diambil dari dirinya sendiri secara penuh. Segala pembagian tugas dan tanggung jawab dipegang oleh si pemimpin yang otoriter tersebut, sedangkan para bawahan hanya melaksanakan tugas yang telah diberikan.

Kepemimpinan otoriter merupakan gaya kepemimpinan yang paling tua dikenal manusia. Oleh karena itu gaya kepemimpinan ini menempatkan kekuasaan di tangan satu orang atau sekelompok kecil orang yang di antara mereka tetap ada seorang yang paling berkuasa. Pemimpin bertindak sebagai penguasa tunggal. Orangorang yang dipimpin yang jumlahnya lebih banyak, merupakan pihak yang dikuasai, yang disebut bawahan atau anak buah. Kedudukan bawahan semata-mata sebagai pelaksana keputusan, perintah, dan bahkan kehendak pimpinan. Pemimpin memandang dirinya lebih, dalam segala hal dibandingkan dengan bawahannya. Kemampuan bawahan selalu dipandang rendah, sehingga dianggap tidak mampu berbuat sesuatu tanpa perintah. Perintah pemimpin sebagai atasan tidak boleh dibantah, karena dipandang sebagai satu-satunya yang paling benar. Pemimpin sebagai penguasa merupakan penentu nasib bawahannya.

Oleh karena itu tidak ada pilihan lain, selain harus tunduk dan patuh di bawah kekuasaan sang pemimpin. Kekuasaan pimpinan digunakan untuk menekan bawahan, dengan mempergunakan sanksi atau hukuman sebagai alat utama. Pemimpin menilai kesuksesannya dari segi timbulnya rasa takut dan kepatuhan yang bersifat kaku.

Kelebihan model kepemimpinan otoriter ini ada di pencapaian prestasinya. Tidak ada satupun tembok yang mampu menghalangi langkah pemimpin ini. Ketika dia memutuskan suatu tujuan, itu adalah harga mati, tidak ada alasan, yang ada adalah hasil. Langkah - langkahnya penuh perhitungan dan sistematis. 
Dingin dan sedikit kejam adalah kelemahan pemimpin dengan kepribadian merah ini. Mereka sangat mementingkan tujuan sehingga tidak pernah peduli dengan cara apapun. Makan atau dimakan adalah prinsip hidupnya.

3. Tipe Kepemimpinan Otoriter

Tipe kepemimpinan yang otoriter biasanya berorientasi kepada tugas. Artinya dengan tugas yang diberikan oleh suatu lembaga atau suatu organisasi, maka kebijaksanaan dari lembaganya ini akan diproyeksikan dalam bagaimana ia memerintah kepada bawahannya agar kebijaksanaan tersebut dapat tercapai dengan baik. Di sini bawahan hanyalah suatu mesin yang dapat digerakkan sesuai dengan kehendaknya sendiri, inisiatif yang datang dari bawahan sama sekali tak pernah diperhatikan.

4. Ciri / Indikator Kepemimpinan Otoriter

Adapun ciri/indikator kepemimpinan otoriter menurut Sutikno (2007) dalam Devi :

a. Segala keputusan diambil oleh pimpinan.

b. Tugas bawahan sangat diperinci oleh pimpinan.

c. Dalam bersikap kepada bawahan, pimpinan melibatkan perasaan pribadi sehingga lebih bersifat subjektif.

d. Pimpinan memberikan kesempatan kepada bawahan untuk mengajukan pendapat akan tetapi semua keputusan berada pada pimpinan.

e. Pimpinan mengawasi pekerjaan bawahan dengan ketat.

\subsection{Kerangka Konsep Penelitian}

Berdasarkan teori yang dikemukakan dalam topic sebelumnya, maka dapat disusun kerangka pemikiran sebagai berikut :

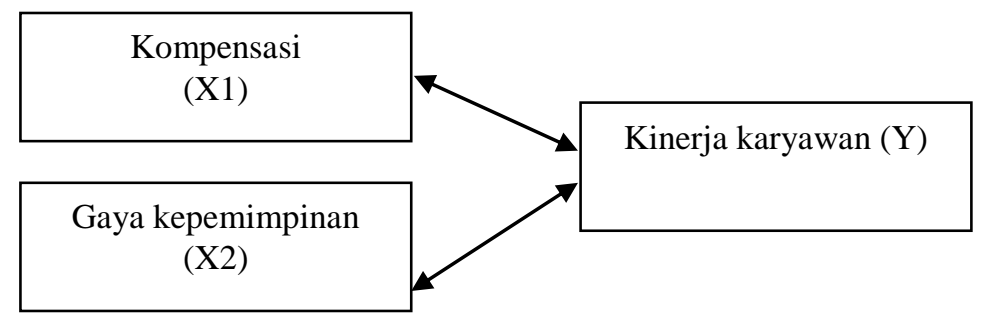

Gambar 2.2 Kerangka Konseptual Penelitian

\subsection{Hipotesis}

Berdasarkan rumusan masalah yang ada, tujuan penelitian, dan landasan teori dapat di tarik hipotesis sebagai berikut :

1. Terdapat hubungan yang signifikan antara Kompensasi dengan Kinerja Karyawan PT. Circle K Indonesia Utama Surabaya.

2. Terdapat hubungan yang signifikan antara Gaya Kepemimpinan Otoriter dengan Kinerja Karyawan PT. Circle K Indonesia Utama Surabaya.

\section{Metode Penelitian}

\subsection{Pendekatan Penelitian}

Penelitian ini menggunakan pendekatan kuantitatif atau metode survey. Metode survey adalah metode yang mengambil contoh data dari satu populasi dan menggunakan kuesioner sebagai alat pengumpulan data yang pokok (Singarimbun dan Effendi, 1989). Dengan metode tersebut diharapkan upaya pemahaman hubungan variabel kompensasi dan gaya kepemimpinan otoriter dengan kinerja karyawan.

\subsection{Populasi dan Sampel}

Populasi yang digunakan sebagai penelitian minimarket Circle K yang berada di Surabaya yaitu yang berada dalam wilayah Area Koordinator II yang dipimpin Bpk. Gio. Populasinya yaitu pekerja di Circle K Surabaya, sedangkan sampel adalah semua karyawan yang berada pada Area Koordinator 2 yaitu berjumlah 68 orang. Definisi Sampel merupakan suatu bagian dari populasi yang akan diteliti dan yang dianggap dapat menggambarkan populasinya (Soehartono, 2004:57).

Teknik pengambilan sampel dalam penelitian ini adalah teknik sensus. Mengingat jumlah populasi di Area Koordinator 2 yang tidak begitu besar maka seluruh anggota populasi berjumlah 68 orang dipilih sebagai sampel. 


\subsection{Jenis, Sumber dan Teknik Pengambilan Data}

1. Dalam penelitian ini data-data yang diperoleh diklasifikasikan menjadi dua jenis, yaitu :

a. Data Primer : Data yang diperoleh secara langsung dari sumber hukum pertama atau objek penelitian. Dalam penelitian ini data primer diperoleh dari wawancara bebas dengan narasumber, yaitu suatu metode pengumpulan data dengan mengajukan pertanyaan yang telah disusun dalam daftar pertanyaan yang berhubungan dengan masalah yang diteliti.

b. Data Sekunder : Data yang diperoleh dari objek penelitian yang berhubungan dengan penelitian ini, yang meliputi gambaran umum subjek penelitian.

2. Teknik Pengambilan Data Pengumpulan data dalam penelitian ini diperoleh dengan cara-cara sebagai berikut:

a. Teknik kuesioner

Teknik kuesioner dilakukan dengan cara penyebaran daftar pertanyaan kepada seluruh responden.

b. Teknik wawancara

Teknik wawancara merupakan suatu cara mencari data dengan mengajukan pertanyaan secara langsung atau lisan kepada subjek penelitian, yaitu karyawan toko PT Circle K Indonesia Utama Surabaya.

\subsection{Variabel dan Definisi Operasional}

\subsubsection{Variabel}

Berdasarkan uraian permasalahan dan hipotesis yang diajukan, variabel dalam penelitian ini terdiri dari variabel bebas (X) yaitu Kompensasi (X1), Gaya kepemimpinan otoriter (X2) dan variabel terikat kinerja (Y).

1. Variabel terikat (Y)

Variabel terikat dalam penelitian ini adalah kinerja karyawan bagian toko PT Circle K Indonesia Utama Surabaya.

2. Variabel bebas $(\mathrm{X})$

Variabel bebas (X) dalam penelitian ini adalah Kompensasi (X1) dan Gaya Kepemimpinan otoriter (X2)

\subsubsection{Definisi Operasional}

Untuk menjelaskan apa yang dimaksut dengan variabel-variabel penelitian yang diidentifikasi, maka perlu diberikan definisi operasional sebagai berikut :

1. Variabel terikat (Y) kinerja karyawan

Merupakan variabel yang dipengaruhi atau menjadi akibat karena adanya variabel bebas.

Pada penelitian ini variabel terikatnya adalah kinerja karyawan bagian toko PT Circle K Indonesia Utama Surabaya. Pengukuran variabel kinerja karyawan dilakukan dengan menggunakan indikator :

a. Kuantitas. Jumlah yang harus diselesaikan atau dicapai. Melibatkan perhitungan keluaran dari proses atau pelaksanaan kegiatan.

b. Kualitas. Merupakan mutu yang harus dihasilkan. Pengukuran kualitatif mencerminkan pengukuran tingkat kepuasan yaitu seberapa baik penyelesaiannya.

c. Ketepatan waktu. Tingkat aktivitas diselesaikan pada waktu yang ditetapkan atau sesuai tidaknya dengan waktu yang direncanakan.

2. Variabel bebas (X1) kompensasi

Merupakan variabel yang menjadi sebab timbulnya atau berubahnya variabel terikat. Bisa disebut juga variabel yang mempengaruhi.

Pada penelitian ini variabel bebas (X1) adalah kompensasi. Pengukuran variabel kompensasi dilakukan dengan menggunakan indikator :

a. Upah atau Gaji. Upah biasanya berhubungan dengan tarif gaji per jam. Upah merupakan basis bayaran yang kerapkali digunakan bagi pekerja-pekerja produksi. Gaji umumnya berlaku untuk tarif bayaran mingguan, bulanan atau tahunan.

b. Insentif. Tambahan kompensasi di atas atau di luar gaji atau upah yang diberikan.

c. Tunjangan.Contoh-contoh tunjangan adalah asuransi kesehatan dan jiwa, liburan yang ditanggung perusahaan, program pension, dan tunjangan lainnya yang berkaitan dengan hubungan kepegawaian.

d. Fasilitas. Contoh-contoh fasilitas adalah kenikmatan/fasilitas seperti mobil perusahaan, keanggotaan klub, tempat parkir khusus, atau akses ke pesawat perusahaan yang diperoleh karyawan. Fasilitas dapat mewakili jumlah substansial dari kompensasi, terutama bagi eksekutuf yang dibayar mahal.

3. Variabel bebas (X2) gaya kepemimpinan otoriter

Variabel bebas yang kedua adalah gaya kepemimpinan otoriter, sehingga semua keputusan berada pada pimpinan. Pengukuran variabel gaya kepemimpinan dilakukan dengan menggunakan indikator :

a. Segala keputusan diambil oleh pimpinan.

b. Tugas bawahan sangat diperinci oleh pimpinan.

c. Dalam bersikap kepada bawahan, pimpinan melibatkan perasaan pribadi sehingga lebih bersifat subjektif. 
d. Pimpinan memberikan kesempatan kepada bawahan untuk mengajukan pendapat akan tetapi semua keputusan berada pada pimpinan.

e. Pimpinan mengawasi pekerjaan bawahan dengan ketat.

\subsection{Desain Instrument Penelitian}

Dalam rangka menyusun daftar pertanyaan penelitian kedalam bentuk kuesioner, berikut ini disajikan desain instrumen penelitian:

Tabel 3.1Desain Instrumen Penelitian

Sumber: Data olahan (Peneliti,2016)

\begin{tabular}{|c|c|c|}
\hline $\begin{array}{c}\text { Variabel } \\
\text { Penelitian }\end{array}$ & Indikator & Skala \\
\hline $\begin{array}{c}\text { Kompensasi } \\
\text { (X1) }\end{array}$ & $\begin{array}{ll}\text { 1. } & \text { Upah dan gaji }(X 1.1) \\
\text { 2. } & \text { Insentif }(X 1.2) \\
\text { 3. } & \text { Tunjangan }(X 1.3) \\
\text { 4. } & \text { Fasilitas }(X 1.4) \\
\text { Simamora }(2004: 445)\end{array}$ & $\begin{array}{l}\text { Likert } \\
\text { Likert } \\
\text { Likert } \\
\text { Likert }\end{array}$ \\
\hline $\begin{array}{c}\text { Gaya } \\
\text { Kepemimpinan } \\
\text { (X2) }\end{array}$ & $\begin{array}{l}\text { 1. Segala keputusan diambil oleh pimpinan (X2.1) } \\
\text { 2. Tugas bawahan sangat diperinci oleh pimpinan (X2.2) } \\
\text { 3. Dalam bersikap kepada bawahan, pimpinan melibatkan perasaan } \\
\text { pribadi sehingga lebih bersifat subjektif (X2.3) } \\
\text { 4. Pimpinan memberikan kesempatan kepada bawahan untuk } \\
\text { mengajukan pendapat akan tetapi semua keputusan berada pada pimpinan } \\
\text { (X2.4) } \\
\text { 5. Pimpinan mengawasi pekerjaan bawahan dengan ketat (X2.5) } \\
\text { Sutikno (2007) }\end{array}$ & $\begin{array}{l}\text { Likert } \\
\text { Likert }\end{array}$ \\
\hline $\begin{array}{c}\text { Kinerja } \\
\text { Karyawan (Y) }\end{array}$ & $\begin{array}{l}\text { 1. Kuantitas (Y1.1) } \\
\text { 2. Kualitas (Y1.2) } \\
\text { 3. Ketepatan waktu (Y1.3) } \\
\text { Dharma (2003:355) }\end{array}$ & $\begin{array}{l}\text { Likert } \\
\text { Likert } \\
\text { Likert }\end{array}$ \\
\hline
\end{tabular}

\subsection{Teknik Analisis Data}

Penelitian ini bertujuan untuk mengukur hubungan antara satu variabel dengan variabel lainnya, selain itu karena data yang digunakan adalah data ordinal, maka penulis menggunakan Korelasi Rank Spearman sebagai alat uji dalam penelitian ini. Korelasi Rank Spearman tidak mengikuti asumsi normalitas dan linieritas sehingga data yang digunakan dalam hal ini adalah ordinal tidak perlu lagi ditransformasikan kedalam bentuk interval seperti persyaratan untuk pengujian korelasi Pearson Product Moment.

\subsubsection{Uji Validitas dan Reliabilitas}

Terdapat dua syarat utama yang harus dipenuhi oleh alat pengumpulan data (instrument / kuisioner) sebelum alat itu digunakan, kedua syarat itu adalah valid dan reliable.

\subsubsection{Uji Validitas}

Uji validitas dilakukan untuk mengetahui apakah suatu instrumen alat ukur telah menjalankan fungsi ukurnya. Validitas menunjukkan ketepatan dan kecermatan alat ukur dalam melakukan fungsi ukurnya. Untuk mengetahui konsistensi dan akurasi data yang dikumpulkan dari penggunaan instrumen dilakukan uji validitas dengan menggunakan korelasi produk momen.

Suatu skala pengukuran disebut valid bila ia melakukan apa yang seharusnya dilakukan dan mengukur apa yang seharusnya diukur. Bila skala pengukuran tidak valid maka ia tidak bermanfaat bagi peneliti karena tidak mengukur apa yang seharusnya diukur atau melakukan apa yang seharusnya dilakukan. Pada penelitian ini validitas yang di uji adalah validitas konstruk (construct validity) dengan mengkorelasikan skor masing-masing butir dengan skor total. Skor total sendiri adalah skor yang didapat dari penjumlahan skor butir untuk instrumen tersebut.

Perhitungan dilakukan dengan menggunakan korelasi product moment. Untuk mempercepat uji validitas dihitung dengan program SPSS versi 18. Uji signifikansi validitas dilakukan dengan membandingkan $r$ hitung dengan $r_{\text {tabel. }}$ Bagi butir pertanyaan yang tidak valid maka akan dikeluarkan dari daftar pertanyaan dan tidak digunakan pada analisis selanjutnya (Ghozali, 2005:45). 


\subsubsection{Uji Reliabilitas}

Pengujian reliabilitas adalah berkaitan dengan masalah adanya kepercayaan terhadap instrumen. Suatu instrumen dapat memiliki tingkat kepercayaan yang tinggi (konsisten) jika hasil dari pengujian instrumen tersebut menunjukkan hasil yang tetap. Dengan demikian, masalah reliabilitas instrumen berhubungan dengan masalah ketepatan hasil. Uji reliabilitas dilakukan untuk mengetahui tingkat kestabilan suatu alat ukur. Pada penelitian, uji reliabilitas dilakukan dengan menggunakan pendekatan internal consistency reliability yang menggunakan Cronbach Alpha untuk mengidentifikasikan seberapa baik item-item dalam kuisioner berhubungan antara satu dengan yang lainnya.

Untuk mempercepat uji reliabilitas dihitung dengan program SPSS versi 18. Sebuah faktor dinyatakan reliabel/handal jika koefisien Alpha lebih besar dari 0,6.

\subsection{Pengertian Korelasi}

Korelasi merupakan teknik analisis yang termasuk dalam salah satu teknik pengukuran asosiasi/hubungan (measure of association). Tujuan dari analisis korelasi adalah untuk mengetahui apakah diantara dua variabel terdapat hubungan atau tidak, dan jika ada hubungan bagaimanakah arah hubungan dan seberapa besar hubungan tersebut.

Dalam korelasi sempurna tidak diperlukan lagi pengujian hipotesis, sebab kedua variabel mempunyai hubungan linear yang sempurna.

\subsection{Asumsi Dasar Penggunaan korelasi}

Kedua variabel bersifat independen satu dengan lainnya, artinya masing-masing variabel berdiri sendiri dan tidak tergantung satu dengan lainnya. Tidak ada istilah variabel bebas dan variabel tergantung. Jika digunakan istilah variabel $\mathrm{X}$ dan $\mathrm{Y}$ itu hanya untuk mempermudah dalam penghitungan melalui rumus yang ada.

Data untuk kedua variabel berdistribusi normal untuk korelasi Pearson. Data yang mempunyai distribusi normal artinya data yang distribusinya simetris sempurna dengan nilai rata-rata di puncak dan nilai-nilai di atas dan dibawah rata-rata simetris.

\subsubsection{Analisa Korelasi}

Teknik analisis data yang akan dilakukan dalam penelitian ini menggunakan metode uji korelasi Rang Spearman untuk mengetahui hubungan antara variabel $\mathrm{X}$ dengan variabel $\mathrm{Y}$. Alasan penggunaan teknik pengujian ini merupakan ukuran asosiasi yang membentuk kedua variabel diukur sekurang-kurangnya dalam skala ordinal, sehingga objek-objek atau individu yang dipelajari dapat dirangking.

Korelasi Rank Spearman digunakan untuk mencari hubungan atau untuk menguji signifikansi hipotesis asosiatif bila masing-masing variabel yang dihubungkan berbentuk Ordinal. Rank Spearman tidak mengikuti asumsi normalitas dan linieritas seperti kepada Korelasi Pearson Product Moment tidak pula menggunakan data interval sehingga hasil uji Spearman ini dapat langsung diinterprestasikan maknanya menggunakan bantuan table intepretasi nilai r. Dalam penelitian untuk mempercepat analisa korelasi dihitung dengan program SPSS versi 18.

\subsection{Hubungan Variabel Bebas dan Terikat}

Kriteria yang digunakan untuk pengambilan keputusan yang menyatakan terdapat hubungan ataupun tidak ada hubungan antara variabel bebas dan variabel terikat dinyatakan dalam kriteria berikut ini :

1. Jika $t$ hitung $>\mathrm{t}$ tabel, maka $\mathrm{H} 0$ ditolak, yaitu terdapat hubungan antara variabel bebas dengan variabel terikat.

2. Jika $\mathrm{t}$ hitung $<\mathrm{t}$ tabel, maka $\mathrm{H} 1$ diterima, yaitu tidak terdapat hubungan antara variabel bebas dengan variabel terikat.

\section{Hasil Penelitian Dan Pembahasan \\ 4.1.Deskripsi Operasional \\ 4.1.1.Gambaran Umum Obyek Penelitian}

Circle $\mathrm{K}$ adalah sebuah perusahaan yang bergerak di bidang retail. Circle $\mathrm{K}$ sangat terkenal di seluruh dunia dengan menawarkan produk-produk berkualitas dan juga pelayanan cepat dan ramah. Ditambah lagi dengan lingkungan yang bersih serta suasana yang menyenangkan, menciptakan pengalaman berbelanja yang berbeda.

Gerai Circle K saat ini dapat dijumpai hampir di berbagai belahan dunia seperti di Amerika Serikat, Meksiko, Jepang, Macau, China, Taiwan, Hong Kong, dan Indonesia. Circle K pertama kali hadir di Indonesia pada tahun 1986 di kota Jakarta, di Jalan Panglima Polim, Jakarta Selatan. Circle K kemudian merambah keluar 
Jakarta dengan membuka toko luar jakarta pertamanya di Bali pada tahun 1996, Circle K Yogyakarta menyusul pada tahun 2000, Circle K Bandung juga menyusul tahun 2001. Saat ini Circle K memiliki gerai di hampir setiap kota besar di seluruh Indonesia dan mempekerjakan lebih kurang 700 tenaga kerja di Indonesia, Circle K memiliki jaringan di Jakarta (23 gerai), Bandung (7 gerai), Yogyakarta (38 gerai), Bali (42 gerai), Surabaya (23 gerai), Batam, dan Makassar (9 gerai).

\subsubsection{Validitas dan Reliabilitas}

\section{Uji Validitas}

Salah satu masalah dalam penelitian ini cara memperoleh data yang akurat dan obyektif. Hal ini menjadi sangat penting sebab kesimpulan yang diambil hanya akan dapat dipercaya bila didasarkan pada data yang akurat. Untuk itu dalam penelitian ini perlu diketahui seberapa tinggi reliabilitas dan validitas kuesioner yang digunakan.

Yang dimaksud dengan validitas adalah suatu derajat ketepatan item-item dalam kuesioner untuk mengukur suatu variabel penelitian. Analisis validitas ini bertujuan untuk menguji apakah tiap butir pertanyaan benar-benar telah sahih, paling tidak dapat menetapkan derajat yang tinggi dari kedekatan data yang diperoleh dengan apa yang diyakini ada dalam pengukuran dengan menggunakan Product Moment Pearson (Maholtra, 1996:306)

\begin{tabular}{ccccc} 
Variabel & Items & $\begin{array}{c}\text { Koefisien } \\
\text { Korelasi } \\
\text { (rhitung) }\end{array}$ & $\begin{array}{c}\text { Nilai Kritis } \\
\text { (rtabel) }\end{array}$ & Keterangan \\
\hline X1 & X1.1 & .775 & 0,2387 & Valid \\
& X1.2 & .698 & 0,2387 & Valid \\
& X1.3 & .559 & 0,2387 & Valid \\
X2 & X1.4 & .645 & 0,2387 & Valid \\
& X2.1 & .663 & 0,2387 & Valid \\
& X2.2 & .606 & 0,2387 & Valid \\
& X2.3 & .733 & 0,2387 & Valid \\
& X2.4 & .461 & 0,2387 & Valid \\
X3 & X2.5 & .639 & 0,2387 & Valid \\
& Y01 & .576 & 0,2387 & Valid \\
& Y02 & .730 & 0,2387 & Valid \\
& Y03 & .677 & 0,2387 & Valid \\
\hline
\end{tabular}

Sumber: Data Primer Diolah,2016

Pada tabel diatas dapat diketahui bahwa pertanyaan-pertanyaan dalam kuesioner tersebut dinyatakan valid karena nilai signifikansinya lebih kecil dari 0,05 dan nilai korelasinya dari tiap item pertanyaan lebih besar dari nilai kritisnya, atau $\mathrm{r}$ hitung > r kritis. Oleh karena itu, dapat dikatakan validitas alat ukur dapat dipenuhi. Dengan demikian, kuesioner yang diajukan kepada responden dapat dinyatakan valid, berarti kuesioner itu mampu mengukur apa yang hendak diukur dan mampu mengungkap apa yang hendak diungkap dalam penelitian.

2. Reliabilitas

Uji reliabilitas dilakukan terhadap instrumen pengumpul data yang dikerjakan dengan menggunakan program SPSS versi 18, hasil perhitungan lengkap terdapat pada lampiran.

Tabel 4.6

Case Processing Summary

\begin{tabular}{llrr}
\multicolumn{4}{c}{ Case Processing Summary } \\
\hline \multirow{4}{*}{ Cases } & N & \multicolumn{1}{c}{$\%$} \\
& Valid & 68 & 100,0 \\
& Excluded $^{\mathrm{a}}$ & 0 &, 0 \\
& Total & 68 & 100,0 \\
\hline
\end{tabular}

Pada tabel 4.5 terlihat uji coba dengan menggunakan responden 68 dan semua responden tidak ada yang excluded atau dikeluarkan dari analisis.

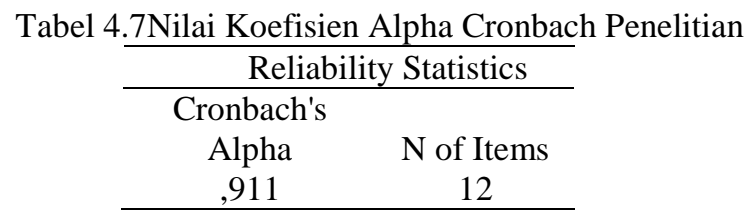

Pada tabel 4.6 tersebut tampak semua variabel baik variabel bebas atau variabel terikat memiliki nilai koefisien Alpha Cronbach > 0,60 dengan demikian dapat dikatakan bahwa semua variabel yang digunakan 
dalam penelitian ini dinyatakan reliabel. Sehingga dapat menghasilkan data yang benar atau dapat mewakili keadaan yang sesungguhnya. Sehingga pada uji validitas dan reabilitas disimpulkan bahwa data yang digunakan valid dan reliabel.

\subsection{Analisa Data dan Pengujian Hipotesis}

\subsubsection{Analisa Data}

Tujuan utama dari penelitian ini adalah mencari hubungan antara variabel bebas yang terdiri dari kompensasi dan gaya kepemimpinan dengan variabel terikat yaitu kinerja karyawan oleh karena skala atau pengukuran data dengan menggunakan data ordinal, maka proses pengolahan data tersebut menggunakan analisa korelasi rank spearman. Sehingga pengolahan datanya adalah mencari hubungan antar dua variabel. Hasil pengolahan data dengan program SPSS versi 18 seperti dibawah ini.

Tabel 4.8Hasil Analisa Data

\begin{tabular}{|c|c|c|c|c|c|}
\hline & & & $\mathrm{X} 1$ & $\mathrm{X} 2$ & $\mathrm{Y}$ \\
\hline \multirow[t]{9}{*}{ Spearman's rho } & \multirow[t]{3}{*}{$\mathrm{X} 1$} & Correlation Coefficient & 1,000 &, $728^{* *}$ &, $825^{* * *}$ \\
\hline & & Sig. (2-tailed) & &, 000 & ,000 \\
\hline & & $\mathrm{N}$ & 68 & 68 & 68 \\
\hline & \multirow[t]{3}{*}{$\mathrm{X} 2$} & Correlation Coefficient &, $728^{* *}$ & 1,000 &, $702^{* *}$ \\
\hline & & Sig. (2-tailed) &, 000 & & ,000 \\
\hline & & $\mathrm{N}$ & 68 & 68 & 68 \\
\hline & \multirow[t]{3}{*}{$\mathrm{Y}$} & Correlation Coefficient &, $825^{* *}$ &, $702^{* *}$ & 1,000 \\
\hline & & Sig. (2-tailed) &, 000 &, 000 & \\
\hline & & $\mathrm{N}$ & 68 & 68 & 68 \\
\hline
\end{tabular}

**. Correlation is significant at the 0.01 level (2-tailed).

Pada tabel korelasi tersebut besarnya korelasi antara kompensasi (X1) dengan kinerja karyawan (Y) adalah sebesar 0.825 dengan tingkat signifikansi 0,000 .

Hubungan Kompensasi (X1) dengan Gaya kepeminpinan otoriter (X2) bisa dikatakan kuat dan signifikan karena nilai koefisien korelasi mempunyai hasil 0,728 dengan tingkat signifikansi 0,000.

1. Hubungan Kompensasi (X1) dengan kinerja karyawan (Y) bisa dikatakan sangat kuat dan signifikan karena nilai koefisien korelasi mempunyai hasil 0,825 dengan tingkat signifikansi 0,000.

2. Hubungan Gaya kepemimpinan otoriter (X2) dengan kinerja karyawan (Y) bisa dikatakan kuat dan signifikan karena nilai koefisien korelasi mempunyai hasil 0,702 dengan tingkat signifikansi 0,000.

Output dari SPSS uji Rank Spearman tersebut diartikan menggunakan tabel interpretasi nilai $r$ yang bisa dilihat di tabel berikut ini :

Tabel 4.9Interpretasi Nilai $\mathrm{r}$

\begin{tabular}{cc}
\hline Interval Koefisien & Tingkat Hubungan \\
\hline $0,00-0,199$ & Sangat Rendah \\
$0,20-0,399$ & Rendah \\
$0,40-0,599$ & Sedang \\
$0,60-0,799$ & Kuat \\
$0,80-1,000$ & Sangat Kuat \\
\hline
\end{tabular}

Sumber : Sugiyono, 2007.

\subsubsection{Pengujian Hipotesis}

Peneliti akan menjabarkan pembuktian hipotesis agar penjelasan hubungan tiap variabel lebih jelas dan fokus. Hipotesis-hipotesis ini mempunyai rincian sebagai berikut :

1. Hipotesis I :

Tingkat signifikansi yang dimiliki antara variabel Kompensasi (X1) dengan variabel gaya kepemimpinan otoriter (X2) adalah 0,000 dan $0,000<0,05$ yang berarti signifikansi sudah terpenuhi dan dapat dinyatakan bahwa $\mathrm{H}_{0}$, dipastikan bahwa terdapat korelasi yang positif dan signifikan antara variabel Kompensasi (X1) dengan variabel kinerja karyawan (Y)

2. Hipotesis II :

Tingkat signifikansi yang dimiliki antara variabel kompensasi (X1) dengan variabel kinerja karyawan (Y) adalah 0,000 dan 0,000 $<0,05$ yang berarti signifikansi sudah terpenuhi dan dapat dinyatakan bahwa $\mathrm{H}_{0}$ 
ditolak. Dan bisa dipastikan bahwa terdapat korelasi yang positif dan signifikan antara variabel Kompensasi (X1) dengan variabel kinerja karyawan (Y).

3. Hipotesis III :

Tingkat signifikansi yang dimiliki antara variabel gaya kepemimpinan otoriter (X2) dengan variabel kinerja karyawan $(\mathrm{Y})$ adalah 0,000 dan $0,000<0,05$ yang berarti signifikansi sudah terpenuhi dan dapat dinyatakan bahwa $\mathrm{H}_{0}$ ditolak. Dan bisa dipastikan bahwa terdapat korelasi yang positif dan signifikan antara variabel gaya kepemimpinan otoriter (X2) dengan variabel Kinerja Karyawan (Y).

\subsubsection{Pembahasan Hasil Penelitian}

Sebagaimana telah diuraikan pada bab terdahulu tujuan penelitian ini adalah untuk mengetahui seberapa besar hubungan kompensasi dan gaya kepemimpinan otoriter dengan kinerja karyawan, maka bersama ini penulis menyampaikan pembahasan atas hasil pengolahan data, yaitu : Hubungan kompensasi (X1) dengan kinerja karyawan $(\mathrm{Y})$ mempunyai hasil yang paling tinggi yaitu 0,825 , jika diartikan dengan menggunakan tabel $\mathrm{r}$ berada pada antara $0,80-1,000$ yang berarti tingkat hubungan sangat kuat dengan tingkat signifikansi 0,000 yang berarti $0,000<0,05$ maka tingkat signifikansi sudah terpenuhi. Maka bisa dikatakan bahwa kompensasi (X1) dengan kinerja karyawan (Y) mempunyai hubungan yang sangat kuat dan signifikan.

Selanjutnya hubungan dengan hasil tertinggi kedua dimiliki oleh variabel gaya kepemimpinan (X1) dengan variabel gaya kepmimpinan otoriter (X2) dengan hasil korelasi 0,728 yang diartikan menurut tabel interpretasi nilai $\mathrm{r}$ berada pada antara $0,60-0,799$ yang berarti tingkat hubungan kuat dan mempunyai tingkat signifikansi 0,000 yang berarti tingkat signifikansi telah terpenuhi. Maka bisa dikatakan bahwa variabel kompensasi (X1) dengan gaya kepemimpinan (X2) mempunyai hubungan yang kuat dan signifikan.

Hubungan yang mempunyai hasil yang paling rendah adalah variabel gaya kepemimpinan otoriter (X2) dengan variabel kinerja karyawan $(\mathrm{Y})$ yang mempunyai hasil 0,702 yang diartikan menurut tabel interpretasi $\mathrm{r}$ berada pada antara 0,60 - 0,799 mengindikasikan tingkat hubungan kuat dengan nilai signifikansi 0,000 yang berati tingkat signifikansi telah terpenuhi. Maka bisa dikatakan variabel gaya kepemimpinan otoriter (X2) dengan variabel kinerja karyawan $(\mathrm{Y})$ mempunyai hubungan yang kuat dan signifikan walaupun mempunyai nilai korelasi yang paling rendah dibandingkan dengan hubungan yang lainnya.

Jadi, diantara kedua variabel tersebut yang mempunyai nilai hubungan paling tinggi adalah kompensasi. Oleh karena itu jika kompensasi yang diberikan dirasakan adil oleh karyawan dan besarnya tidak jauh berbeda dengan yang diharapkan oleh karyawan serta gaya kepemimpinan yang sesuai dengan lingkungan maka semakin meningkat kinerja karyawan dan sebaliknya apabila semakin kurang adil dalam pemberian kompensasi kepada karyawan serta gaya kepemimpinan tidak sesuai maka semakin rendah kinerja karyawan pada PT Circle K Indonesia Utama Surabaya.

\section{Kesimpulan Dan Saran \\ 5.1.Kesimpulan}

Penelitian ini bertujuan untuk mengetahui hubungan antara kompensasi dan gaya kepemimpinan dengan kinerja karyawan pada karyawan PT. Circle K Indonesia Utama Surabaya, maka ditarik beberapa kesimpulan yaitu : Dugaan Hipotesis penelitian terbukti bahwa terdapat Hubungan antara kompensasi dan gaya kepemimpinan otoriter dengan kinerja karyawan, yang mana mempunyai hubungan yang tinggi yaitu kompensasi dengan kinerja karyawan terlihat dari $r$ korelasi sebesar 0,825 ( $r$ terletak antara 0,80 sampai 1,000). Sedangkan gaya kepemimpinan dengan kinerja karyawan sebesar 0,702 ( $\mathrm{r}$ terletak antara 0,60 sampai 0,799 ). Sehingga dapat diartikan, bahwa kompensasi dan gaya kepemimpinan otoriter mempunyai kontribusi yang besar terhadap kinerja karyawan.

\subsection{Saran}

Saran yang dapat diberikan berdasarkan pembahasan adalah sebagai berikut:

1. Diharapkan agar pihak Circle $\mathrm{K}$ terus memperhatikan antara pemberian kompensasi kepada para karyawannya. Dikarenakan semakin karyawan diperhatikan akan kompensasi yang sesuai dengan kinerja karyawan tersebut, karyawan akan semakin giat dalam melaksankan pekerjaan.

2. Kompensasi yang diberikan kepada karyawan sebaiknya tepat pada waktu yang telah ditentukan perusahaan agar rasa kepercayaan karyawan terhadap perusahaan semakin besar sehingga kinerja karyawanpun akan semakin meningkat.

3. Perusahaan harus memperhatikan pimpinan atau supervisor mereka. Diperlukan adanya bimbingan untuk saling mendukung satu sama lain didalam team toko. Sehingga tidak saling menjatuhkan satu sama lain.

4. PT. Circle K Indonesia Utama Surabaya sebaiknya meningkatkan lagi lingkungan kerja yang ada, yaitu kenyamanan tempat kerja dan penambahan peralatan kerja untuk memperlancar pekerjaan serta perlu diperhatikan juga hubungan antara karyawan satu dengan yang lain ataupun atasan dalam rangka menciptakan hubungan kerja sama yang semakin baik. 
5. Diharapkan kepada peneliti yang akan meneliti permasalahan yang sejenis, diharapkan memasukkan variabel lain diluar variabel yang sudah ada dalam penelitian ini.

\section{Daftar Pustaka}

Nawawi,Hadari.2012. Kepemimpinan yang efektif. Yogyakarta. Gadhah Mada University Press.

Edwin B. Fillipo.1994. Manajemen Personalia. Jakarta. Erlangga

Veitzal Rivai dan Ella J. Sagala. 2009. Manajemen Sumber Daya Manusia. Jakarta. Rajawali Pers

Rivai, Prof. Dr. Veithzal M.B.A dan Mulyadi, Prof. Dr. Deddy M.Si. 2003. Kepemimpinan dan Perilaku Organisasi. PT. Rajagrafindo Persada. Jakarta.

Yusuf Burhanuddin. 2015. Manajemen Sumber Daya Manusia. Rajagrafindo Persada. Jakarta.

Handoko,T Hani. 2011. Manajemen Personalia Dan Sumber Daya Manusia. BPFE. Yogyakarta.

Surya Devi agni. Analisa pengaruh gaya kepemimpinan otoriter dan lingkungan kerja terhadap kepuasan kerja karyawan departemen room division Swiss-Belinn Hotel Manyar Surabaya, Surabaya. Universitas Petra

Romadhon S. 2012. Hubungan gaya kepemimpinan autokratis dengan kinerja karyawan bagian pemasaran PT Puji Surya Indah Surabaya. Universitas Narotama. Surabaya.

Jurnal Manajemen, ISSN 2302-0199

Jurnal Ekonomi, Bisnis \& Entrepreneurship, 08(01). ISSN 2443-0633

Tampubolon, Saur M. 2013. Pengaruh Gaya Kepemimpinan, Lingkungan Kerja, dan Harapan Dosen terhadap Kepuasan Kerja. Jurnal Pendidikan dan Kebudayaan.

Safitri, Husnaini M. 2012. Pengaruh Gaya Kepemimpinan, Kerjasama Tim, Dan Gaya Komunikasi Terhadap Kepuasan Kerja Serta Dampaknya Terhadap Kinerja Pegawai Pada Sekretarit Daerah Kota Sabang. Universitas Syiah Kuala. Banda Aceh.

Mangkunegara, P. A. A. (2009). Manajemen Sumber Daya Manusia, Cetakan Kesembilan. Bandung. Remaja Rodakarya.

Dharma, S. (2005). Manajemen Kinerja. Pustaka Pelajar. Jakarta.

Mangkunegara, A. P. (2002). Manajemen Sumber Daya Manusia. Remaja $\quad$ Rosdakarya.

Rivai, V., \& Sagala, E. J. (2013). Manajemen Sumber Daya Manusia untuk Perusahaan. Dari Teori ke Praktik Edisi Kedua.

Hasibuan, S. P. Malayu. 2006. Manajemen Sumber Daya Manusia. Edisi Revisi. Bumi Aksara. Jakarta.

Hasibuan, H. Malayu S.P, Manajemen Sumber Daya Manusia, Edisi Revisi Kedua, Penerbit BPFE-UGM, Yogyakarta.

Noto Atmodjo, Soekidjo, Pengembangan Sumber Daya Manusia, Cetakan Ke-2, Penerbit Reneka Cipta, Jakarta. 